\title{
A brief review on motor development: fundamental motor skills as a basis for motor skill learning
}

\author{
RODOLFO N. BENDA ${ }^{1}$ | NÁDIA F. S. MARINHO² | MARCELO G. DUARTE | PATRICK C. RIBEIRO-SILVA4 | PALOMA R. \\ ORTIGAS ${ }^{5}$ | CAMILA F. MACHADO ${ }^{6}$ | THÁBATA V. B. GOMES7
}

1 Universidade Federal de Pelotas, Pelotas, RS, Brazil.

${ }^{2}$ Centro Universo Belo Horizonte, Belo Hosiroznte, MG, Brazil.

3 Universidade Federal de Mato Grosso do Sul, Corumbá, MS, Brazil.

${ }^{4}$ Centro Universitário do Sul de Minas UNIS, Varginha, MG, Brazil.

${ }^{5}$ Pós-Graduação em Educação Física, Universidade Federal de Pelotas, Pelotas, RS, Brazil.

${ }^{6}$ Centro Universitário da Região da Campanha URCAMP; Pós-Graduação em Educação Física, Universidade Federal de Pelotas, Pelotas, RS, Brazil.

7 Universidade Federal de Pelotas, Pelotas, RS, Brazil.

Correspondence to: Rodolfo Novellino Benda. Universidade Federal de Pelotas, Pelotas, RS, Brazil. http://orcid.org/0000-0002-9785-8323

email: rodolfobenda@yahoo.com.br

https://doi.org/10.20338/bjmb.v15i5.257

\section{HIGHLIGHTS \\ - A relationship between motor development and motor learning is presented. \\ - A new metaphor of the sequence of motor development is proposed. \\ - Findings of studies that evaluated the performance of fundamental skills are analyzed. \\ - Fundamental skills are considered essential \\ to motor development in lifespan.}

\section{ABBREVIATIONS}

ADHD Attention deficit and hyperactivity disorder

ASD Autism spectrum disorder

DCD Developmental coordination disorder

PUBLICATION DATA

Received 04082021

Accepted 01102021

Published 01122021

\section{ABSTRACT}

In this study, we review the relationship between motor development and motor learning, and present a new metaphor that represents the sequence of motor development, which highlights fundamental motor skills as an important phase in the process. As one of the most relevant phases of motor development, several studies that analyzed fundamental motor skills were reviewed in typical developing children as well as in children with disabilities. Most studies revealed motor performance levels below expected since proficiency was not observed. We discuss these results considering fundamental motor skills as essential for the motor development process. Such results raise the awareness of the need to offer children conditions to explore and experience motor activities in order to enhance motor competence.

KEYWORDS: Motor Development | Motor learning | Fundamental motor skills

\section{INTRODUCTION}

In this study, we review two important topics of motor development literature: the relationship between motor development and motor learning and the sequence of motor development. Our interpretation is that these topics still need further clarification to better address the motor development phenomenon. Traditionally, motor development is not discussed along with motor learning, as most of the textbooks present these topics separately. Even though they are distinct phenomena, they occur simultaneously in individuals. In light of that, we propose an integrated approach, which considers that motor skills learning constitutes motor development in the lifespan. In other words, motor learning is present in almost all phases of motor development.

Regarding the sequence of motor development, it is mainly represented by 
geometric figures (triangle or trapeze), an hourglass, or a mountain. All these metaphors are inanimate structures, which may be inadequate to represent how complex processes occurs in living beings. Moreover, we highlight the importance of fundamental motor skills in the sequence, placing this category of movements as central in the motor development process. We then present a new metaphor, represented by a living being and suggesting a new look at the phases of motor development.

As a basis for motor development, the learning of fundamental motor skills is an important step in order to learn new skills along with the lifespan. Thus, a review of studies that investigated fundamental motor skills is presented, and several findings have revealed a low performance of children, which may negatively influence the learning of skills in the future. We discuss these results with concern, as they indicate that learning new motor skills may be compromised.

\section{MOTOR DEVELOPMENT AND MOTOR LEARNING}

Motor development is understood as changes in motor behavior through lifespan as well as the processes that underlie these changes. ${ }^{1}$ Definitions in the main textbooks of Motor Development are based on this simple concept. For example, according to Payne and Isaacs, ${ }^{2}$ "motor development refers to the changes that occur in our ability to move and our movement in general as we proceed through the lifespan" (p. 2). In the same way, Gallahue, Ozmun and Goodway 3 propose motor development as "the continuous changes in motor behavior throughout the lifespan, due to the interaction between motor task requirement, the individual biology, and the environment conditions" (p. 21). Still, "motor development refers to the continuous, age-related process of change in movement as well as the interacting constraints (or factors) in the individual, environment, and task that drive these changes" (p. 36). ${ }^{4}$ Thus, the definition of motor development seems to be established, as all textbooks presented similar notions to this phenomenon.

However, it was not found definitions of motor development that mention other related processes of motor behavior, such as motor learning. In fact, motor development is different from motor learning, although both are changes in motor behavior. We might differ motor learning from motor development according to two main aspects. Firstly, the time scale needed to promote changes. In motor learning, changes are already seen in minutes, hours, or days while in motor development changes spend months, years, or decades. Second, the main factor that drives changes. In motor learning, we consider the practice as this main factor while motor development changes occur due to time.

Regarding the time scale, even complex tasks are learned in a relatively short time. For example, how long does it take to learn to drive a car? Well, the answer depends on the learner characteristics, obviously, but we might speculate that between 48 and 96 hours of practice would be enough to observe changes that enable the learner to pass on specific exams. This time spent in practice would represent two to four days, which is little when compared with the entire lifespan. On the other hand, motor development deals with ontogenetic time, which involves all periods of human life. These periods are divided according to an approximated age, and named as infancy, childhood, adolescence, adulthood, senescence. Thus, the movements and skills predominant in each period of life are then grouped and categorized. Motor development deals more with these categories 
than with individual skills or movements. In other words, this categorization allows us to identify which motor skills would be taught at each age.

The second factor is practice, which is very important in motor learning. In order to learn any skill, we have to practice it. Whether we want to play the guitar, skateboard or juggle, we need to practice in a class with a teacher, a coach, or even alone. This rule may be also extended to the skills that a child learns early in life, as crawling, walking, running, and so on. All skills are learned, that is, they certainly pass for a motor learning process. Practice is also present in motor development. Some theoretical conceptions suggest that genetic aspects are the main aspect that results in development. On the other hand, recent conception proposes that genetic aspects interact with the environmental conditions, which include family education, social relations, culture, as well as practice and motor experience, among others. ${ }^{5}$

Again, motor development is understood as changes in motor behavior through lifespan. ${ }^{1}$ Following this concept, motor learning is a process that promotes changes in motor behavior and it occurs, obviously, in the lifespan. In other words, motor learning is included in the motor development spectrum. As all skills are learned, the motor skill will integrate a repertoire of skills of each person, which composes the motor history of that person, that is, motor development. Thus, motor development can be seen as an ensemble of all movements and skills that human being included in motor history. Even in this view, a motor development sequence can be seen, in which categories are presented according to the periods of life.

\section{SEQUENCE OF MOTOR DEVELOPMENT}

The sequence of motor development has been described for a long time and it relies on a hierarchical principle, in which new skills are learned based on the previous ones. ${ }^{3,6}$ First movements observed in human motor behavior are reflex and spontaneous movements. ${ }^{6}$ Reflex movements are involuntary, they need a stimulus to be performed,

and they are stereotyped, that is, they are always executed in the same way. ${ }^{3,6}$ On the other hand, spontaneous movements do not need a stimulus, but they are performed without an apparent goal, for example, kicks and arms swing. ${ }^{6}$ As for the skills, they are voluntary and directed to a specific goal, and are observed early in life, in the first year of life. In this phase, the children start to explore the environment around them not only with hands or legs but with the entire body. As maturation occurs, the nervous system improves its control over muscles, and the children are able to stabilize their bodies and free their hands to reach, grasp and manipulate objects. ${ }^{2}$ As balance improves, children assume other postures with autonomy, such as sitting or standing, in addition to becoming able to move through rolling, crawling, creeping, and walking. 2,3,4,7 Reflexes, spontaneous movements, and the first voluntary skills are predominant until two years, approximately. We named this phase Reflex Movements and Exploratory Skills.

In the sequence, children start to experience different motor skills, trying new movements and possibilities, which leads to an increased motor repertoire. For instance, children start to run based on their walking experience, and similarly, they start to gallop and to skip based on their running experience and so on. This new phase is called Fundamental Skills. As the name suggests, fundamental motor skills are considered basic for all skills that will be learned in the lifespan. They are defined as building blocks of more 
advanced and complex motor skills. ${ }^{3,8}$ More specifically, they may be understood as "the most representative or salient skills that, if mastered, will give children the best possible chance to successfully and persistently participate in a range of health-enhancing physical activities" (p. 220). ${ }^{9}$

The fundamental motor skills phase comprises locomotor, manipulative, and stability skills, ${ }^{3}$ and children would present proficiency in performing these skills, as well as their combination. In other words, at the beginning of this phase, skills performance is disorganized, with low accuracy and rhythmic fluency. As practice occurs, children may present an organized, economical, fluent, and accurate behavior in these skills. ${ }^{3,} 6$ After presenting proficiency, what is expected to happen until seven years, approximately, ${ }^{3}$ the fundamental motor skills will be combined or modified in order to be used in the future. For example, specific situations might require combining or adapting fundamental skills, as they will not always be performed according to the proficient pattern. ${ }^{6}$ It is suggested that the combination occurs between seven and ten year. ${ }^{3}$ In our proposal, the fundamental skills phase includes not only the period in which skills are learned and refined but also the period of their combination.

The last phase is called Specialized skills, which comprises complex and detailed skills commonly seen in sports, dance, martial arts, some professions, manual skills, and music (e.g., playing a musical instrument). In some way, every skill that is available to learn and presents some specific goals to be reached might be considered a specialized skill. These skills are influenced by rules, tradition, education, culture, and so on. Among several specialized skills, a person would dedicate to a reduced number of these skills, e.g. when someone chooses a specific sport to practice. With practice, such skills tend to be refined and improved until an expert performance would be achieved. ${ }^{10}$ In this case, these specialized skills would present a skilled level of performance, while the other specialized skills would present a proficient performance. ${ }^{11}$

As we are presenting our interpretation of the sequence of motor development, we will also propose a new metaphor that may illustrate its different phases. We suggest the Rose Metaphor.

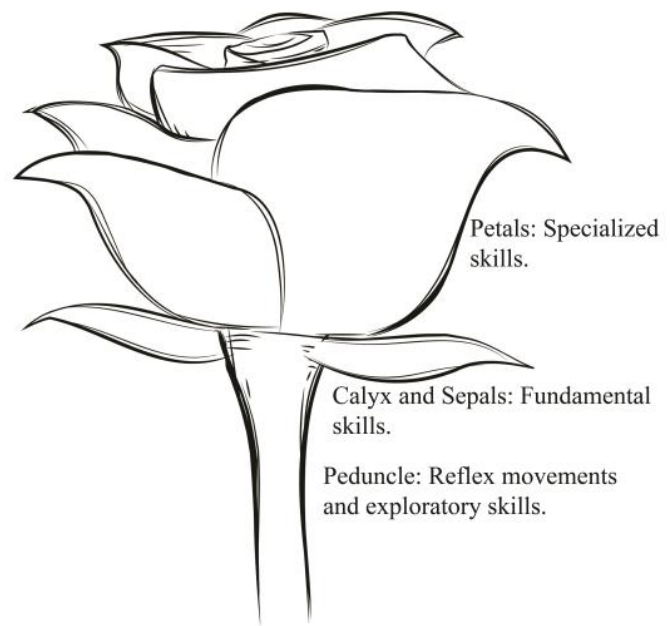

Figure 1. Sequence of motor development - Rose metaphor 
Different from all other metaphors, in nature, it is possible to see a narrower basis than the structure that it supports. In a rose, the peduncle is the basis of the flower, which includes other structures that are responsible for some functions, such as reproduction. ${ }^{12}$ Thus, the peduncle represents the Reflex movement and exploratory skills phase, which do not contain many movements. Distinct from previous metaphors, in which the basis is wider than the other phases, in a rose, the basis is narrower than the other phases, reflecting a smaller number of movements than the skills observed in subsequent phases. Above the peduncle, there are the calyx and sepals. In fact, a calyx is a group of sepals, whose main role is the protection of the flower bud, which is important to allow the growth of petals. ${ }^{12}$ In other words, the calyx and the sepals are essential to the development of petals, as in motor development, in which fundamental motor skills support the development of specialized skills. The petals are the most prominent part of the flower and represent specialized skills. But, some petals are bigger than others, some petals are different from others, which means that not all specialized skills present the same level of performance.

Another difference from this metaphor of the sequence of motor development to all other metaphors is that a rose is a living being. Compared to a triangle, a trapezium, an hourglass, or a mountain, a living being allows a better illustration of a process that occurs in another living being. A rose is born, grows, becomes mature, and withers in its lifespan. A rose follows a developmental sequence similar to that of a human being. In a mature period and the senescence, the performance of specialized skills may deteriorate, and some adaptation may be necessary, changing the motor pattern of the skill, for example. In the rose metaphor, this is illustrated by the petals' withering.

\section{FUNDAMENTAL MOTOR SKILLS}

After presenting the proposal of the Rose metaphor, we would like to highlight de importance of fundamental motor skills to the development of specialized skills. As we have presented, fundamental motor skills are considered the basis for the specialized skills learning ${ }^{9,13}$ as well as to the physical activity in adolescence ${ }^{14,15}$ and in adulthood ${ }^{16}$. On one hand, some specialized skills result from the combination of fundamental motor skills, such as the polka type chassè, which is a combination of gallop and skipskills. ${ }^{17}$ On the other hand, some specialized skills are derivation from some fundamental motor skills, such as kicking a ball in a football game, which is a specialized skill based on the kick skills performed by a child (fundamental skill). ${ }^{3}$ We can also speculate a third reason, in which a vast repertoire of fundamental motor skills may help to learn some specialized skill6. However, this still is a hypothesis that must be tested. The transition from fundamental motor skills to specialized skills needs to be more studied, as the factors that allow this change are not all known.

As we have previously emphasized, fundamental motor skills are conceived as a basis for specialized skills learning. This notion suggests a hierarchy, in which the skills learned before support the subsequent skills. Some factors that have been cited in this process are age, similarity, proficiency, and practice.3,6. Age is related to the time of maturation and experience. However, it is important to highlight that age is not the main factor, as we can see children with the same age and distinct levels of motor development. 
Likewise, it is possible to see children of different ages with the same level of motor development. ${ }^{6}$ Even though the age may influence the transition to specialized skills, it is not the most important factor. Similarity is understood as the relationship between the movement patterns of the components of fundamental motor skills and specialized skills. The closer the components, the more similar are the skills. In other words, some fundamental motor skills present similar components to the specialized skills, which may facilitate this transition. 3,6

Proficiency, which has been proposed as a factor, is the mechanically efficient, coordinated, and controlled performance. ${ }^{3}$ The degrees of freedom are organized and the skill performance is fluent. A proficient fundamental skill is ready to adapt or combine in order to reach the goals of the specialized skill. For example, proficient throwing was important to the performance of volleyball serve, ${ }^{18}$ javelin throwing, and clear do badminton. ${ }^{19}$ Although proficiency may be a factor that contributes to the transition to specialized skills, "...the novel task can be accomplished with various degrees of proficiency, thus permitting the learner to move on even though the task is not performed well" (p. 320).20 Therefore, is possible to learn a specialized skill without a proficient fundamental motor skill. In this case, the practice may be preponderant. Practice can be seen as free experimentation or systematic practice. The latter has been considered more efficient than the former. ${ }^{21,22}$ Nevertheless, even if practice leads to learning, its effects are greater when the fundamental motor skills are proficient. ${ }^{23,24}$

One more time, as we have stated, fundamental motor skills are important to motor development, however children around the world have not presented the expected proficiency in such skills. Studies in different countries and regions have found that children between three and ten years are not reaching proficiency in fundamental motor skills. ${ }^{25-35}$ More specifically, until five years, children present an expected behavior, but from six to ten years, children did not reach proficiency, and they seem to be delayed in motor development. ${ }^{30,34,35}$ Moreover, other studies suggest the lower performance of girls in relation to boys. $33,36-40$

With regard to children with disabilities (atypical developing children), we analyzed studies that investigated the fundamental motor skills level of children with a physical disability (as cerebral palsy), intellectual disability, sensory disabilities (visual impairment and auditory impairment), and neurodevelopment disorders (autism spectrum disorder ASD, attention deficit and hyperactivity disorder - ADHD, developmental coordination disorder - DCD). In physical disability children, some studies have found worse motor performance than typical developing children, ${ }^{41,42}$ and positive effects of motor intervention programs. ${ }^{43,44}$ Children with intellectual disability have presented worse performance than typically developing children, ${ }^{45-47}$ with better performance to children that attended interventions, ${ }^{47}$ as well as better performance of children with mild level than moderate or severe levels of disability. ${ }^{48-50}$

Children with autism spectrum disorder presented fundamental skills performance below average due to poor communicative skills, ${ }^{51,52,53}$ or to a sensorial dysregulation specific to this disorder. ${ }^{54}$ Children with attention deficit and hyperactivity disorder also presented scores below expected in fundamental motor skills. ${ }^{55,56}$ The developmental coordination disorder presents a prevalence of $6 \%$ of the population and is characterized by clumsiness and marked impairment in the development of motor coordination. $57-59$ Studies have shown that children with DCD did not reach proficiency in fundamental 
skills. ${ }^{60,61}$ Sensory disabilities also lead to poor performance in fundamental motor skills, in visual impairment, ${ }^{62,63}$ as well as in hearing impairment. ${ }^{64}$

\section{CONCLUSIONS}

In this short review, we wanted to debate some topics that seem to be unsettled, such as the relationship between motor development and motor learning, the metaphor that represents the sequence of motor development, and the role of fundamental motor skills on motor learning. Motor development is composed of several moments of motor skills learning throughout life. As new motor skills are learned, the motor repertoire increases, which amplifies the extent of motor development. In order to represent this process, we proposed the rose metaphor, based on a living being, where the basis is thinner but strong enough to support the other phases. Moreover, a central phase is emphasized, in which fundamental motor skills provide all the support for the specialized skills to be learned. Then, the focus on fundamental motor skills is an important agenda in motor development research.

In general, children have not shown the expected proficiency in fundamental skills, both in typically developing children and in children with disabilities. The aforementioned findings raise an important issue since children seem to be delayed in the development of fundamental skills. This subject deserves attention, as problems in the children's motor development may be related to the changes in social and economic structures of society, due to urbanization processes, technological innovations, and modernization, as well as changes in the daily habits of the modern man.65 It is important to emphasize that the motor development process is a result of the interaction between genetic characteristics and environmental and cultural influences that surround the individual, as the human being is embedded in a socio-cultural context.5,66-69

Therefore, the results of the presented studies reveal a concern for professionals who work with children, as they indicate a problem in the motor development process. As children in the present time did not develop as expected, and urbanization processes and technological innovations may influence their motor performance, it is important to offer them adequate stimulation in order to reach proficiency in fundamental skills. This is particularly crucial considering that these skills are essential to the learning of subsequent skills. It is important to highlight that fundamental skills constitute the basis not only for specialized skills learning ${ }^{3,4,6}$ but also for adolescent and adult behavior related to physical activity and health benefits. ${ }^{14-16}$ Moreover, we suggest in this study that fundamental skills are the basis for motor learning after childhood.

As we have proposed, fundamental motor skills are considered one of the most important phases of motor development, as they are the foundation for all specialized skills that will be learned and performed in lifespan. As a matter of fact, a recent study has shown interesting data confirming this statement. ${ }^{70}$ Children should have the opportunity to learn and refine fundamental motor skills, because, as we have seen, in current days these skills are not proficient, since the studies have shown performances below expected. It is important to make efforts so that children have the opportunity to practice and perform fundamental skills. Some actions have been presented as effective for a better performance of fundamental skills, such as physical education classes taught by specialized teachers, ${ }^{71}$ sports practice, ${ }^{34}$ the school context, ${ }^{72}$ and motor interventions. ${ }^{73,74}$ 
However, the importance of fundamental motor skills and motor experiences in childhood still do not have the necessary appreciation from society, parents, and professionals who work directly with children. We expect that this scenario may change as soon as possible, in order to favor the next generation of children to have the optimal conditions for motor development.

\section{REFERENCES}

1. Clark JE, Whitall J. What is motor development? The lessons of history. Quest. 1989;41(3):183-202. https://doi.org/10.1080/00336297.1989.10483969

2. Payne VG, Isaacs LD. Human motor development: a lifespan approach. 8.ed. New York, NY: McGraw-Hill, 2012, p.548.

3. Gallahue DL, Ozmun JC, Goodway JD. Compreendendo o desenvolvimento motor: bebês, crianças, adolescentes e adultos. 7.ed. Porto Alegre, RS: AMGH, 2013, p. 487.

4. Haywood KM, Getchell N. Life span motor development. 6.ed. Champaign, IL: Human Kinetics, 2014, p. 700.

5. Basso L, Santos FG, Benda RN. Estudo do desenvolvimento motor: tendências e perspectivas. 2016 In: Tani G. (Ed.), Comportamento motor: conceitos, estudos e aplicações. Rio de Janeiro, Guanabara Koogan. Pp25-30.

6. Clark JE, Metcalfe JS. The mountain of motor development: a metaphor. 2002 In: Clark JE, Humphrey J. (Eds.). Motor development: Research and reviews v. 2. Reston, NASPE Publications. Pp163-190.

7. Adolph KE, Vereijken B, Denny MA. Learning to crawl. Child Dev. 1998;69(5):1299-1312. https://doi.org/10.1111/j.1467-8624.1998.tb06213.x

8. Logan SW, Ross SM, Chee K, Stodden DF, Robinson LE. Fundamental motor skills: A systematic review of terminology. J Sports Sci. 2018;36(7):781-796. http://dx.doi.org/10.1080/02640414.2017.1340660

9. Barnett LM, Stodden DF, Cohen KE, Smith JJ, Lubans DR, Lenoir M, et al. Fundamental movement skills: An important focus. J Teach Phys Educ. 2016;35(3):219-225. https://doi.org/10.1123/jtpe.2014-0209

10. Ericsson KA, Krampe RT, Tesch-Römer $\mathrm{C}$. The role of deliberate practice in the acquisition of expert performance. Psychol Rev. 1993;100(3):363-406. https://doi.org/10.1037/0033295X.100.3.363

11. Ferreira LP, Marinho NFS, Ribeiro-Silva PC, Brito WS, Benda RN. O volume de prática em ginástica artística influencia o desempenho das habilidades motoras fundamentais.

Pensar a Prát. 2021;24: e68099. https://doi.org/10.5216/rpp.v24.68099

12. Santos DYC, Motta LB. Diversidade da morfologia floral. 2008 In: Santos DYC, Chow F, Furlan CA. (Eds.). A botânica no cotidiano. São Paulo, Universidade de São Paulo. Pp1318. 
13. Barnett LM, Lai SK, Veldman SLC, Hardy LL, Cliff DP, Morgan PJ, et al. Correlates of gross motor competence in children and adolescents: A systematic review and metaanalysis. Sports Med. 2016;46(11): 1663-1688. doi: 10.1007/s40279-016-0495-z.

14. Barnett LM, Van Beurden E, Morgan PJ, Brooks LO, Beard JR. Childhood motor skill proficiency as a predictor of adolescent physical activity. J Adolesc Health. 2009;44(3):252-259. 10.1016/j.jadohealth.2008.07.004

15. Lubans DR, Morgan PJ, Cliff DP, Barnett LM, Okely AD. Fundamental movement skills in children and adolescents: review of associated health benefits. Sports Med. 2010;40(12):1019-1035. doi: 10.2165/11536850-000000000-00000

16. Stodden DF, Goodway JD, Langendorfer SJ, Roberton MA, Rudsill ME, Garcia C, et al. A developmental perspective on the role of motor skill competence in physical activity: An emergent relationship. Quest. 2008;60(2):290-306. https://doi.org/10.1080/00336297.2008.10483582

17. Marinho NFS, Aburachid LMC, Gomes TVB, Ribeiro-Silva PC, Duarte MG, Flor IHG, et al. Evidence of content, concurrent criterion validity, and reliability in a chassè checklist. Hum Mov. 2021;22(3):62-69. https://doi.org/10.5114/hm.2021.100325

18. Costa CLA, Benda RN, Matos CO, Bandeira PFR, Lage GM, Ugrinowitch H. Effect of development level in fundamental motor skills in the specialized skill performance. Motricidade. 2018;14(S1):31-39. http://dx.doi.org/10.6063/motricidade.14610

19. O'Keefee S, Harrison A, Smith P. Transfer or specificity? An applied investigation into the relationship between fundamental overarm throwing and related sport skills. Phys Educ Sport Peda. 2007;12(2):89-102. https://doi.org/10.1080/17408980701281995

20. Seefeldt $V$. Developmental motor patterns: implications for elementary school physical education. 1980 In: Nadeau C, Halliwell W, Newell K, Roberts C. (Eds.). Psychology of motor behavior and sport. Champaign, Human Kinetics. Pp.314-323.

21. Logan SW, Robinson LE, Wilson AE, Lucas WA. Getting the fundamentals of movement: A meta-analysis of the effectiveness of motor skill interventions in children. Child Care Health Dev. 2012;38(3):305-315. https://doi.org/10.1111/j.1365-2214.2011.01307.x

22. Morgan PJ, Barnett LM, Cliff DP, Okely AD, Scott HA, Cohen KE, et al. Fundamental movement skill interventions in youth: a systematic review and meta- analysis. Pediatrics. 2013;132(5):e1361-83. https://doi.org/10.1542/peds.2013-1167

23. Costa CLA. Estrutura de prática e nível de desenvolvimento motor na aprendizagem da habilidade especializada [dissertação de mestrado em Ciências do Esporte]. Belo Horizonte: Escola de Educação Física Fisioterapia e Terapia Ocupacional da Universidade Federal de Minas Gerais; 2015. 91p.

24. Marinho NFS. Fatores que influenciam na transição entre habilidades motoras fundamentais e especializadas. [tese de doutorado]. Belo Horizonte: Escola de Educação Física Fisioterapia e Terapia Ocupacional da Universidade Federal de Minas Gerais; 2019. 133p. 
25. Afonso GH, Freitas DL, Carmo JM, Lefevre JÁ, Almeida MJ, Lopes VP, et al. Desempenho motor. Um estudo normativo e criterial em crianças da Região Autónoma da Madeira, Portugal. Rev Port Ciênc Desporto. 2009;9(2- 3):160-174.

26. Bardid F, Huyben F, Lenoir M, Seghers J, Martelaer K, Goodway JD, et al. Assessing fundamental motor skills in Belgian children aged 3-8 years highlights differences to US reference sample. Acta Paediatr. 2016;105(6):281-290. doi: 10.1111/apa.13380. Epub 2016 Mar 22.

27. De Meester A, Stodden DF, Brian A, True L, Cardon G, Tallir I, et al. Associations among elementary school children's actual motor competence, perceived motor competence, physical activity and BMI: A cross-sectional study. Plos One. 2016;11(10): 1-14. doi: 10.1371/journal.pone.0164600. eCollection 2016.

28. Lopes VP, Saraiva L, Gonçalves C, Rodrigues LP. Association between perceived and actual motor competence in Portuguese children. J Mot Learn Dev. 2018;6(2):366-377. https://doi.org/10.1123/jmld.2016-0059

29. Ré AHN, Tudela MC, Monteiro CB, Antonio B, Silva MMDLM, Campos CMC, et al. Competência motora em crianças do ensino público da cidade de São Paulo. J Phys Educ. 2018;29(1):1-8. https://doi.org/10.4025/jphyseduc.v29i1.2955

30. Tavares ED, Oliveira KBBD, Silva Júnior FID, Silva IZFD, Carvalhal MIM. Influência de variáveis biológicas e socioculturais no desenvolvimento motor de crianças com idades entre 7 a 9 anos. Motricidade. 2016;12(1):76-84.

31. Cepicka L. Normative data for the Test of Gross Motor Development-2 in 7-years old children in the Czech Republic. Percept Mot Skills. 2010;110(3):1048-1052. doi: 10.2466/pms.110.C.1048-1052.

32. Idamokoro M, Daniel T, Lyoka P. Anthropometric and motor development characteristics of rural children in Nkonkobe Municipality, South Africa. Med. Sport, 2019;72(1):112-126. doi: 10.23736/S0025-7826.18.03419-1

33. Morano M, Bortoli L, Ruiz MC, Campanozzi A, Robazza C. Actual and perceived motor competence: Are children accurate in their perceptions? Plos One. 2020;15(5):1-13. https://doi.org/10.1371/journal.pone.0233190

34. Ribeiro-Silva PC, Marinho NFS, Brito WS, Costa NE, Benda RN. Motor performance in basic skills of children participants and nonparticipants of oriented sport practice. J Phys Educ. 2018;29(e2903):1-11. doi: 10.4025/jphyseduc.v29i1.2903

35. Mukherjee S, Ting Jamie LC, Fong LH. Fundamental motor skill proficiency of 6- to 9-yearold Singaporean children. Percept Mot Skills. 2017;124(3):584-600.

doi:10.1177/0031512517703005

36. Aye T, Oo KS, Khin MT, Kuramoto-Ahuja T, Maruyama H. Reliability of the test of gross motor development second edition (TGMD-2) for kindergarten children in Myanmar. J Phys Ther Sci. 2017;29(10):1726-1731. doi: 10.1589/jpts.29.1726

37. Cohen KE, Morgan PJ, Plotnikoff RC, Callister R, Lubans DR. Fundamental movement skills and physical activity among children living in low-income communities: a cross- 
sectional study. Int J Behav Nutr Phys Act. 2014;11,(49):1-9. doi: 10.1186/1479-5868-1149.

38. Field SC, Temple VA. The relationship between fundamental motor skill proficiency and participation in organized sports and active recreation in middle childhood. Sports. 2017;5(2):43. doi: 10.3390/sports5020043

39. Queiroz DDR, Henrique RDS, Feitoza AHP, Medeiro JNSD, Souza CJFD, Lima TDJS, et al. Competência motora de pré-escolares: Uma análise em crianças de escola pública e particular. Motricidade. 2016;12(3):56-63. http://dx.doi.org/10.6063/motricidade.6886

40. Yang SC, Lin SJ, Tsai CY. Effect of sex, age, and BMI on the development of locomotor skills and object control skills among preschool children. Percept Mot Skills.

2015;121(3):873-888. https://doi.org/10.2466/10.PMS.121c29x0

41. Hamilton M, Goodway JD, Haubenstricker J. Parent-assisted instruction in a motor skill program or at-risk preschool children. Adapt Phys Activ Q. 1999;16(4):415- 426. https://doi.org/10.1123/apaq.16.4.415

42. Kelly L, Dagger J, Walkley J. The effects of an assessment-based physical education program on motor skill development in preschool children. Educ Treat Children. 1989;12(2):152-164. http://www.jstor.org/stable/42899103

43. Alriksson-Schmidt A, Nordmark E, Czuba T, Westbom L. Stability of the gross motor function classification system in children and adolescents with cerebral palsy: A retrospective cohort registry study. Dev Med Child Neurol. 2017;59(6):641-646. https://doi.org/10.1111/dmcn.13385

44. Valentini NC, Rudisill ME. An inclusive mastery climate intervention and the motor skill development of children with and without disabilities. Adapt Phys Activ Q. 2004;21(4),330347. https://doi.org/10.1123/apaq.21.4.330

45. Frey GC, Chow B. Relationship between BMI, physical fitness, and motor skills in youth with mild intellectual disabilities. Int J Obes. 2006;30(5):861-867. doi:10.1038/sj.ijo.0803196

46. Klavina A, Ostrovska K, Campa M. Fundamental movement skill and physical fitness measures in children with disabilities. EUJAPA, 2017;10(1):28-37. doi: 10.5507/euj.2017.004

47. Vargas LM, Gutierrez GL, Cantorani JRH, Pilatti LA, Gorla JI. Desenvolvimento das habilidades motoras fundamentais em crianças com deficiência intelectual: diferença entre os sexos. Cad Pós-Grad Distúrb Desenvolv. 2018;18(1):83-103.

http://dx.doi.org/10.5935/cadernosdisturbios.v18n1p83-103

48. Rintala P, Linjala J. Scores on test of gross motor development of children with dysphasia: A pilot study. Percept Mot Skills. 2003;97(3):755-762. doi:10.2466/pms.2003.97.3.755

49. Hartman E, Houwen S, Scherder E, Visscher C. On the relationship between motor performance and executive functioning in children with intellectual disabilities. J Intellect Disabil Res. 2010;54(5):468-477. doi: 10.1111/j.1365-2788.2010.01284.x 
50. Westendorp M, Houwen S, Hartman E, Visscher C. Are gross motor skills and sport participation related in children with intellectual disabilities? Res Dev Disabil. 2011;32(3):1147-1153. doi:10.1016/j.ridd.2011.01.009

51. Allen KA, Bredero B, Van Damme T, Ulrich DA, Simons J. Test of gross motor development-3 (TGMD-3) with the use of visual supports for children with autism spectrum disorder: Validity and reliability. J Autism Dev Disord. 2017;47(3):813- 833. doi: 10.1007/s10803-016-3005-0

52. Berkeley L, Zittel LL, Pitney LV, Nichols SE. Locomotor and object control skills of children diagnosed with Autism. Adapt Phys Activ Q. 2001;18(4):405-416. https://doi.org/10.1123/apaq.18.4.405

53. Liu T, Hamilton M, Davis L, ElGarhy S. Gross motor performance by children with autism spectrum disorder and typically developing children on TGMD-2. J Child Adolesc Behav. 2014;2(1):123. doi: 10.4172/2375-4494.1000123

54. Staples KL, Reid G. Fundamental movement skills and autism spectrum disorders. J Autism Dev Disord. 2010;40(2):209-217. doi: 10.1007/s10803-009-0854-9

55. Toniolo C, Santos LCA, Lourenceti MD, Padula NAMR, Capellini AS. Caracterização do desempenho motor em escolares com transtorno de déficit de atenção com hiperatividade. Rev Psicopedag. 2009;26(79):33-40. https://www.revistapsicopedagogia.com.br/detalhes/265/

56. Harvey WJ, Reid G. Motor performance of children with attention-deficit hyperactivity disorder: a preliminary investigation. Adapt Phys Activ Q. 1997;14(3):189-202. https://doi.org/10.1123/apaq.14.3.189

57. American Psychiatric Association. Manual diagnóstico e estatístico de transtornos mentais DSM-5 Porto Alegre, RS: Artmed, 2014, p.948.

58. Magalhães LC, Cardoso AA, Missiuna C. Activities and participation in children with developmental coordination disorder: A systematic review. Res Dev Disabil. 2011;32(4);1309-1316. https://doi.org/10.1016/j.ridd.2011.01.029

59. Ferreira LF, Souza CJF, Mendonça ASGB, Freudenheim, AM. Comportamento motor no transtorno do desenvolvimento da coordenação. In: Lage GM, Ribeiro S. (Eds.). Comportamento motor nos transtornos de desenvolvimento. Belo Horizonte, MG: Ampla, 2020, Pp.71-88.

60. Valentini NC, Getchell N, Logan SW, Liang L-Y, Golden D, Rudisill ME, et al. Exploring associations between motor skill assessments in children with, without, and at-risk for developmental coordination disorder. J Mot Learn Dev. 2015;3(1):39-52. https://doi.org/10.1123/jmld.2014-0048

61. Yu J, Sit CH, Capio CM, Burnett A, Ha AS, Huang WY. Fundamental movement skills proficiency in children with developmental coordination disorder: Does physical selfconcept matter? Disabil Rehabil. 2016;38(1):45-51. doi: 10.3109/09638288.2015.1014067. 
62. Haibach PS, Wagner MO, Lieberman LJ. Determinants of gross motor skill performance in children with visual impairments. Res Dev Disabil, 2014;35(10):2577-2584.

http://doi.org/10.1016/j.ridd.2014.05.030

63. Houwen S, Hartman E, Jonker L, Visscher C. Reliability and validity of the TGMD- 2 in primary-school-age children with visual impairments. Adapt Phys Activ Q. 2010;27(2):143159. https://doi.org/10.1123/apaq.27.2.143

64. Gursel F. Inclusive intervention to enhance the fundamental movement skills of children without hearing: A preliminary study. Percept Mot Skills. 2014;118(1):304- 315. doi: 10.2466/10.15.25.PMS.118k14w0

65. Spence JC, Lee RE. Toward a comprehensive model of physical activity. Psychol Sport Exerc. 2003;4,(1):7-24. https://doi.org/10.1016/S1469-0292(02)00014-6

66. Oyama S. Friends, neighbors, and boundaries. Ecol Psychol. 2009;21(2):147-154. http://dx.doi.org/10.1080/10407410902877173

67. Turvey MT. On the notion and implications of organism-environment system. Ecol Psychol. 2009;21(2):97-111. http://dx.doi.org/10.1080/10407410902877041

68. Lewontin RC. The triple helix. Cambridge, MA: Harvard University Press, 2000, p.136.

69. Gottlieb G. Probabilistic epigenesis. Dev Sci. 2007;10(1):1-11. doi: 10.1111/j.14677687.2007.00556.x

70. Costa CLA, Cattuzzo MT, Stodden DF, Ugrinowitsch H. Motor competence in fundamental motor skills and sport skill learning: Testing the proficiency barrier hypothesis. Hum Mov Sci. 2021;80:102877. https://doi.org/10.1016/j.humov.2021.102877.

71. Lemos AG, Avigo EL, Barela JA. Physical education in kindergarten promotes fundamental motor skill development. Adv Physic Educ. 2012;2(1):17-21. doi:10.4236/ape.2012.21003.

72. Cotrim JR, Lemos AG, Neri Junior JE, Barela JA. Desenvolvimento de habilidades motoras fundamentais em crianças com diferentes contextos escolares. Rev Educ Fis UEM. 2011;22(4):523-533. doi: 10.4025/reveducfis.v22i4.12575

73. Braga RC, Krebs RJ, Valentini NC, Tkac CM. A influência de um programa de intervenção motora no desempenho das habilidades locomotoras de crianças com idade entre 6 e 7 anos. Rev Educ Fis UEM. 2009;20(2):171-181. doi: 10.4025/reveducfis.v20i2.6133

74. Van Keulen GE, Benda RN, Ugrinowitsch H, Valentini NC, Krebs RJ. Influência de uma intervenção utilizando a prática variada e em blocos no desempenho das habilidades de controle de objetos. J Phys Educ. 2016;27(1):e2707,1-11. doi:

10.4025/jphyseduc.v27i1.2707 
Citation: Benda RN, Marinho NFS, Duarte MG, Silva PCR, Ortigas PR, Machado CF, Gomes TVB. (2021). A brief review on motor development: fundamental motor skills as a basis for motor skill learning. Brazilian Journal of Motor Behavior, 15(5):342-355.

Editors: Dr Fabio Augusto Barbieri - São Paulo State University (UNESP), Bauru, SP, Brazil; Dr José Angelo Barela São Paulo State University (UNESP), Rio Claro, SP, Brazil; Dr Natalia Madalena Rinaldi - Federal University of Espírito Santo (UFES), Vitória, ES, Brazil.

Copyright:@ 2021 Benda, Marinho, Duarte, Silva, Ortigas, Machado and Gomes and BJMB. This is an open-access article distributed under the terms of the Creative Commons Attribution-Non Commercial-No Derivatives 4.0

International License which permits unrestricted use, distribution, and reproduction in any medium, provided the original author and source are credited.

Funding: There was no funding for this study.

Competing interests: The authors have declared that no competing interests exist.

DOI: https://doi.org/10.20338/bjmb.v15i5.257 